\title{
Inputs Price Transmission Effect on Marketing Margins on Fisheries Products of Iran
}

\author{
Mahdi Saravani ${ }^{1} \&$ Nazar Dahmarde Ghaleno ${ }^{2}$ \\ ${ }^{1}$ School of Management \& Economics, PhD Candidate in Agricultural Economics, University of Sistan and \\ Baluchestan, Zahedan, Iran \\ ${ }^{2}$ School of Management \& Economics, Associate Professor in Economics, University of sistan and Baluchestan, \\ Zahedan, Iran \\ Correspondence: Mahdi Saravani, School of Management and Economics, University of sistan and Baluchestan, \\ Zahedan, Iran. Tel: 9891-5142-3137. E-mail: saravani56@yahoo.com
}

Received: October 8, 2015

Accepted: November 6, 2015

Online Published: December 20, 2015

doi:10.5539/mas.v10n1p184

URL: http://dx.doi.org/10.5539/mas.v10n1p184

\begin{abstract}
Volatility and instability of inputs price and products on the one hand and high marketing margins, on the other hand are the main characters of inefficient marketing of agricultural products. So in this paper we will consider the Prices Transmission of Inputs and Marketing Costs on Marketing Margin of Fisheries Products during 2004 to 2014. The variables examined in this study which were extracted from the website of Fisheries and Statistics Center of Iran, include hot and cold water fish prices (Larve and Fingerling), Fishmeal and Concentrate (inputs), transport and labor costs and amount of used inputs. The results show that Necessary and sufficient conditions for coincidence of inputs price transmission has rejected and mediators through asymmetrical transmission of input prices to retails increase marketing margin and thereby earn profits. The coincident test also in the transfer of marketing costs showed asymmetry coincidence of marketing costs. The variable of total amount of inputs that is considered as an explanatory variable to ensure assume constant returns to scale in marketing margin model, Its impact on marketing margins is incremental and statistically significant. The process trend variable coefficient also shows that market margins will increase over time. To improve this situation it is suggested to establish the Notification institutions of market.
\end{abstract}

Keywords: inputs price transmission, marketing margin, fisheries, Iran

\section{Introduction}

\subsection{Introduce the Problem}

Study the marketing margin and price transmission have always been attractive in the food chain for researchers and agricultural economists and it is used to analyze the efficiency and utilize the market structure. Population growth and increasing demand for healthy food products including fisheries on the one hand And marketing margin and the dissatisfaction of the producers and consumers from the final price of inputs and products on the other hand, make the status Checking of fisheries products market in order to find an approach to improve the marketing and contribute to the development of this important sector necessary. One of the fishery farmer problems is their low intake of the price offered to the consumer products in the consumer market. So that the average of wholesale prices of the north fish, south fish and farmed fish (warm and cool water fish), reached respectively from 12574.6, 12418.2 and 10741 in 2004 to 76106,43390 and 54445 rials reached in 2014 and the average retail price of $15837.6,15860.9$ and 13198.8 rials in 2004 reached to 82504.3, 106072 and 61975 rials in 2014. Study the price paid by the final consumer with regard to the above figures show that the number of North fish, South fish and the farmed in 2004, are 20.6, 21.7 and 18.6 percent to 7.7, 59 and 12.1 percent in 2014, respectively. In other words, in 2014 about 7.7, 59 and 12.1 percent of the price paid by the final consumer (retail level) was the share of the marketing margin (Statistical Yearbook of the Iranian Fisheries Organization, 2014).

\subsection{Explore Importance of the Problem}

Review of past studies shows that because there is no study carried out on the impact of price transition on marketing margin of fishery products and inputs in Iran and the accuracy of the market margin values shows that 
this amount of margin can be created for different reasons which one of these factors is the way price is transferred That could be the result of fish market structure. Therefore if the price transmission is done asymmetric, leads to reducing the welfare of producers and consumers of these products by increasing the marketing margin.

\subsection{Describe Relevant Scholarship}

Aguiar and Santana (2002) investigated the price transmission mechanism for tomatoes, onions, coffee, milk powder, rice and beans using the Houck approach. The results of this study indicate that Increase in the price of tomatoes, coffee, milk powder and cereals market is being transmitted faster than its reduction but in the case of onion and rice transmission price is asymmetric. Guillain and Frankuza (2007) analyzed the price transfer of 12 fish species in the Spanish market in their study. The results showed that Flexibility of transition Price between two markets of wholesale and fishing time is larger than the others while the short-term Flexibilities are smaller than long term Flexibilities of price transition. Price symmetry analysis in this study is indicator of asymmetry in 8 species of consumption fish. Moghadasi (2009) described the price transmission mechanism for two main Iranian agricultural products: namely Pastachio and Date used monthly data over the period 1996.01 to 2006.09. The results of study depict that price transmission according to Houck approach in pistachio market is asymmetric. In other words, price increases are transmitted more completely then its decreases and Error correction model in the date market shows that farm price increases are more rapid and fully transmitted than price decreases. Hosseini et al. (2011) analyzed the Market structure and the effect of the transfer price on the marketing margin of the beef industry in Iran. The results showed that the poor distribution of slaughterhouses and the large number of middlemen in the marketing chain make market structure Non-competitive, reduced the welfare of producers and consumers and as well as asymmetric price transmission and marketing expenses increased marketing margin. Ojogho et al. (2012) examined marketing margin and price transmission for beef in Benin metropolis of Edo state used set of household heads. The result of price transmission regression showed that the long run marketing margin elasticity was 0.906 , while the short run marketing margin elasticity of wholesalers and retailer at retail price were respectively 0.906 and 0.911 . Though beef marketing in Benin is profitable with incomplete price transmission and imperfect transmission of price from the wholesalers to the retailers while the margin between producer and retail price was divergent in the short run. Golitavana et al. (2014) studied the mechanism of price transmission in the markets of cucumber in Iran from March 1996 to November 2010. The results of estimation of error correction model showed that the long-term and short-term speed of price transmission in cucumber market is symmetric during the period of study. There asymmetry suggests that the transmission price will be completely and marketing intermediaries and agents from shocks caused by rising and falling market prices on the margin do not earn interest. Kinnucan and Zhang (2014) showed that the absolute marketing margin responds differently to shifts in retail demand, input supply and technical change in the marketer's production function than does the relative marketing margin. According to studies conducted about the marketing of agricultural products, but little researches has been done in the field of marketing fisheries products, and previous studies only express theoretical approach about affecting of price transmission on marketing margins. Seyf and Mirzade Firoozabad (2015) investigated the impressionability of lamb marketing margin on asymmetric price transmission in their study. The results show that Variables of increase of the live sheep price, reduce of it, the time, cost and protection of meat and spring dummy variable have significant impact on the market margin of sheep meat. Results also showed that changes in the price of live sheep are not fully transferred to the retail and price transmission in the short and long term is asymmetric. Review of past studies shows that because there is no study carried out on the impact of price transition on marketing margin of fishery products and inputs in Iran, therefore in this study, using parametric methods by combination of marketing costs model and Hauck methodology which is presented by Frigon et al. (1999) and evaluate the effect of the price transmission of inputs and marketing costs on marketing margin of fisheries products. Also, due to that cost marketing covers a significant portion of the price paid by consumers, and changes in marketing costs, including transportation and labor costs, lead to a changing the producer share from the price offered to consumers, so evaluation of how marketing costs effect on margin market is also analyzed in this study.

\section{Method}

\subsection{Research Design}

In a Competitive market Situation, the Marketing Cost Model can be expressed by relation (1) where $M M$ is the farm- retail price spread, $Q$ is the quantity of the Fisheries Inputs, and $M C$ is the marketing cost index. The concept of the above-normal profit refers to the ability of marketing firms to maintain progression in the farm-retail price, which spreads above that of the marginal marketing cost. To account for these potential 
deviations derived from the competitive market equilibrium, a further variable is added to the marketing cost model. This variable reflects farm price fluctuations, which could be the source of competitive market deviations through short run or long run asymmetries. Therefore, in a situation of imperfect competition, the marketing cost model will be taken by relation (2) where $\partial$ accounts for competitive market deviations resulting from the farm price instability. The empirical form of relation (2) can be expressed as a linear marketing cost model in a competitive market situation (relation 1), with the $\partial$ variable is added. Hence, relation (2) takes form (3) where $\varepsilon$ is the error term and $\partial$ reflects the competitive market deviations, which are equal to zero in the initial period. The methodology was originally proposed by Houck (1977) to estimate irreversible functions used for developing the $\partial$ term in relation (3). Following Houck's methodology, relation (4) gives $\partial$ where $t$ is a trend variable and the parameters $a_{4}$ and $a_{5}$ indicate the effect on the marketing margin respectively in form of an increase or decrease in wholesale price, and the variables, INCWP and DECWP, respectively represent the cumulative increase and decrease in wholesale price. Relations (5) and (6) define these variables mathematically as follows. According to the previous studies (Kinnucan \& Forker, 1987), the impact of rising or falling wholesale prices may distribute over time. To test it, $M_{1}$ and $M_{2}$ are the numbers of periods required for full adjustment of marketing margins leading them to an increase or decrease in wholesale price (number of lags), respectively. By incorporating this number of lags with relation (4), the empirical form for $\partial$ is given by relation (7). Substituting $\delta$ by relation (7) in relation (3), relation (8) can access the middleman behavior regarding transmission to retail prices of wholesale price variations. Relation (8) specifies the farm-retail price spread as a function of two main components: the marginal marketing cost reflected by the variables $Q$ and $M C$, and the middleman behavior in the farm-retail price transmission process estimated by the parameters of INCWP and DECWP. MC which can be expressed in this way reflects rising and falling phases in marketing cost, as well as a lagged response in adjustment using the same methodology as above. Thus, MC can be expressed as (9) where $\mathrm{N}_{1}$ and $\mathrm{N}_{2}$ are the numbers of lags for increases and decreases in marketing cost. With substituting relation (9) in relation (8), the complete estimating equation is expressed by relation (10).

$$
\begin{aligned}
& \mathrm{MM}=\mathrm{f}(\mathrm{Q}, \mathrm{MC}) \\
& \mathrm{MM}=\mathrm{f}(\mathrm{Q}, \mathrm{MC}, \partial) \\
& \mathrm{MM}=\mathrm{a}_{0}+\mathrm{a}_{1} \mathrm{MC}+\mathrm{a}_{2} \mathrm{Q}+\partial+\varepsilon \\
& \partial=\mathrm{a}_{3} \mathrm{t}+\mathrm{a}_{4} \text { INCWP }+\mathrm{a}_{5} \text { DECWP } \\
& \operatorname{INCWP}=\sum_{\mathrm{i}=1}^{\mathrm{K}}\left(\mathrm{WP}_{\mathrm{t}}-\mathrm{WP}_{\mathrm{t}-1}\right) \quad \text { for } \quad \mathrm{WP}_{\mathrm{t}}>\mathrm{WP}_{\mathrm{t}-1} \\
& \operatorname{DECWP}=\left|\sum_{\mathrm{i}=1}^{\mathrm{K}}\left(\mathrm{WP}_{\mathrm{t}}-\mathrm{WP}_{\mathrm{t}-1}\right)\right| \quad \text { for } \quad \mathrm{WP}_{\mathrm{t}}<\mathrm{WP}_{\mathrm{t}-1} \\
& \delta=\mathrm{a}_{3} \mathrm{t}+\sum_{\mathrm{i}=0}^{\mathrm{M} 1} \mathrm{a}_{4 \mathrm{~A}, \mathrm{i}} \mathrm{INCWP}_{\mathrm{t}-\mathrm{i}}+\sum_{\mathrm{i}=0}^{\mathrm{M} 2} \mathrm{a}_{5 \mathrm{~B}, \mathrm{i}} \text { DECWP }_{\mathrm{t}-\mathrm{i}} \\
& \mathrm{MM}=\mathrm{a}_{0}+\mathrm{a}_{1} \mathrm{Q}+\mathrm{a}_{2} \mathrm{MC}+\mathrm{a}_{3} \mathrm{t}+\sum_{\mathrm{i}=0}^{\mathrm{M} 1} \mathrm{a}_{4 \mathrm{~A}, \mathrm{i}} \mathrm{INCWP}_{\mathrm{t}-\mathrm{i}}+\sum_{\mathrm{i}=0}^{\mathrm{M} 2} \mathrm{a}_{5 \mathrm{~B}, \mathrm{i}} \mathrm{DECWP}_{\mathrm{t}-\mathrm{i}}+\epsilon_{\mathrm{t}} \\
& \mathrm{a}_{2} \mathrm{MC}=\sum_{\mathrm{i}=0}^{\mathrm{N} 1} \mathrm{a}_{2 \mathrm{C}, \mathrm{i}} \mathrm{INCMC}_{\mathrm{t}-\mathrm{i}}+\sum_{\mathrm{i}=0}^{\mathrm{N} 2} \mathrm{a}_{2 \mathrm{D}, \mathrm{i}} \mathrm{DECMC}_{\mathrm{t}-\mathrm{i}} \\
& M M=\mathrm{a}_{0}+\mathrm{a}_{1} Q+\sum_{i=0}^{N 1} \mathrm{a}_{2 C, i} I N C M C_{t-i}+\sum_{i=0}^{N 2} \mathrm{a}_{2 D, i} D E C M C_{t-i}+ \\
& \mathrm{a}_{3} \mathrm{t}+\sum_{\mathrm{i}=0}^{\mathrm{M} 1} \mathrm{a}_{4 \mathrm{~A}, \mathrm{i}} \mathrm{INCWP}_{\mathrm{t}-\mathrm{i}}+\sum_{\mathrm{i}=0}^{\mathrm{M} 2} \mathrm{a}_{5 \mathrm{~B}, \mathrm{i}} \text { DECWP }_{\mathrm{t}-\mathrm{i}}+\varepsilon_{t}
\end{aligned}
$$

\subsection{Statistical Hypothesis Testing}

To determine the effect of increases and decreases in the price of inputs and other variables affecting the marketing margins, we need a model that in addition to capabilities to study marketing margin, also show the behavior of variables in a state of imperfect competition. Therefore in this approach combines the marketing cost model and Houck's methodology to measuring affects of asymmetry price transmission on marketing margins. This approach also allows the competitive market assumption as well as that of constant return to scale to be relaxed, because in this model the amount of inputs entry as independent variable. Also the basic assumption of this model is that the cause of asymmetric price transmission indeed is the non-competitive structure of the market. So if the price asymmetric transmission hypothesis is accepted; it means that market has non-competitive structure. To test complete marketing cost transmission requires that the cumulative value of the parameters associated with variables INCMC and DECMC are not statistically different from zero or $(1,2)$. Also to test for symmetric marketing cost transmission by middleman, the cumulative value of increase in marketing costs should be equivalent to the cumulative value of decrease in marketing costs (3). Complete inputs price transmission requires that the cumulative value of the parameters associated with variables INCWP and DECWP 
are not statistically different from zero, or $(4,5)$. As mentioned previously, the extreme case of asymmetric Inputs price transmission is long run asymmetry. In order to test for that phenomenon, which reflects permanent, above normal profit for middlemen, the following test is performed (6). To assess short run asymmetry in price transmission, at least one of the following equalities in (7) must be rejected:

$$
\begin{gathered}
\sum_{\mathrm{i}=0}^{\mathrm{N} 1} \mathrm{a}_{2 c, \mathrm{i}}=0 \\
\sum_{\mathrm{i}=0}^{\mathrm{N} 2} \mathrm{a}_{2 \mathrm{D}, \mathrm{i}}=0 \\
\sum_{\mathrm{I}=0}^{\mathrm{N} 1} \mathrm{a}_{2 c, \mathrm{i}}=\sum_{\mathrm{i}=0}^{\mathrm{N} 2} \mathrm{a}_{2 \mathrm{D}, \mathrm{i}} \\
\sum_{\mathrm{i}=0}^{\mathrm{M} 1} \mathrm{a}_{4 \mathrm{~A}, \mathrm{i}}=0 \\
\sum_{\mathrm{i}=0}^{\mathrm{M} 2} \mathrm{a}_{5 \mathrm{~B}, \mathrm{i}}=0 \\
\sum_{\mathrm{i}=0}^{\mathrm{L}} \mathrm{a}_{4 \mathrm{~A}, \mathrm{i}}=\sum_{\mathrm{i}=0}^{\mathrm{L}} \mathrm{a}_{5 \mathrm{~B}, \mathrm{i}} \quad \mathrm{L}=\operatorname{Max}[\mathrm{M} 1, \mathrm{M} 2] \\
\sum_{\mathrm{i}=0}^{\mathrm{J}} \mathrm{a}_{4 \mathrm{~A}, \mathrm{i}}=\sum_{\mathrm{I}=0}^{\mathrm{J}} \mathrm{a}_{5 \mathrm{~B}, \mathrm{i}} \quad \mathrm{J}=0,1, \ldots<\operatorname{Max}[\mathrm{M} 1, \mathrm{M} 2]-1
\end{gathered}
$$

\section{Results}

\subsection{Ancillary Analyses}

\subsubsection{Investigation of the Fisheries Input's Prices and Marketing Margins}

\begin{tabular}{|c|c|c|c|c|c|c|c|c|c|c|c|c|c|}
\hline Year & $\begin{array}{r}\text { Inflati } \\
\text { on } \\
\text { Rate }\end{array}$ & $\begin{array}{r}\text { Marketing } \\
\text { Margin of } \\
\text { Concentrat } \\
\text { e }\end{array}$ & $\begin{array}{r}\text { Concentrat } \\
\mathrm{e} \\
\text { (Retail } \\
\text { Price) }\end{array}$ & $\begin{array}{r}\text { Concentrat } \\
\text { e } \\
\text { (Wholesale } \\
\text { Price) }\end{array}$ & $\begin{array}{r}\text { Marketin } \\
\text { gMargin } \\
\text { of } \\
\text { Fishmeal }\end{array}$ & $\begin{array}{r}\text { Fishmea } \\
\text { 1(Retail } \\
\text { Price) }\end{array}$ & $\begin{array}{r}\text { Fishmeal } \\
\text { (Wholesal } \\
\text { e Price) }\end{array}$ & $\begin{array}{r}\text { Marketin } \\
\text { g Margin } \\
\text { of Larve } \\
\text { and } \\
\text { Fingerlin } \\
\mathrm{g}(\text { Cold } \\
\text { Water } \\
10 \mathrm{gr})\end{array}$ & $\begin{array}{r}\text { Retail } \\
\text { Price of } \\
\text { Larve } \\
\text { and } \\
\text { Fingerlin } \\
g(\text { Cold } \\
\text { Water } \\
10 \text { gr })\end{array}$ & $\begin{array}{r}\text { Wholesal } \\
\text { e Price } \\
\text { of Larve } \\
\text { and } \\
\text { Fingerlin } \\
\mathrm{g}(\text { Cold } \\
\text { Water } \\
10 \mathrm{gr})\end{array}$ & $\begin{array}{r}\text { Marketin } \\
\text { g Margin } \\
\text { of Larve } \\
\text { and } \\
\text { Fingerlin } \\
\text { g(Wam } \\
\text { Water } \\
10 \mathrm{gr})\end{array}$ & $\begin{array}{r}\text { Retail } \\
\text { Price of } \\
\text { Larve } \\
\text { and } \\
\text { Fingerlin } \\
\mathrm{g}(\text { Wam } \\
\text { Water } \\
10 \mathrm{gr})\end{array}$ & $\begin{array}{r}\text { Wholesal } \\
\text { e Price } \\
\text { of Larve } \\
\text { and } \\
\text { Fingerlin } \\
\mathrm{g} \text { (Wam } \\
\text { Water } \\
10 \mathrm{gr})\end{array}$ \\
\hline 2004 & 15.2 & 495 & 1750 & 1255 & 813 & 6023 & 5210 & 160 & 592 & 432 & 160 & 512 & 352 \\
\hline 2005 & 10.4 & 457 & 1860 & 1403 & 853 & 6570 & 5717 & 200 & 675 & 475 & 185 & 590 & 405 \\
\hline 2006 & 11.9 & 316 & 1900 & 1584 & 2041 & 7950 & 5909 & 180 & 714 & 534 & 184 & 640 & 456 \\
\hline 2007 & 18.4 & 375 & 2450 & 2075 & 807 & 7630 & 6823 & 196 & 782 & 586 & 157 & 653 & 496 \\
\hline 2008 & 25.3 & 631 & 3530 & 2899 & 712 & 8045 & 7333 & 200 & 837 & 637 & 179 & 750 & 571 \\
\hline 2009 & 10.8 & 948 & 3650 & 2702 & 1023 & 9025 & 8002 & 210 & 910 & 700 & 202 & 890 & 688 \\
\hline 2010 & 12.4 & 846 & 3745 & 2899 & 945 & 9950 & 9005 & 220 & 1021 & 801 & 185 & 995 & 810 \\
\hline 2011 & 21.5 & 975 & 4650 & 3675 & 1007 & 11420 & 10413 & 260 & 1131 & 871 & 210 & 1163 & 953 \\
\hline 2012 & 30.5 & 1180 & 6930 & 5750 & 930 & 22430 & 21500 & 240 & 1219 & 979 & 270 & 1492 & 1222 \\
\hline 2013 & 34.7 & 1260 & 9760 & 8500 & 1450 & 36850 & 35400 & 280 & 1392 & 1112 & 230 & 1510 & 1280 \\
\hline 2014 & 15.6 & 2330 & 12630 & 10300 & 3250 & 43250 & 40000 & 320 & 1535 & 1215 & 390 & 1805 & 1415 \\
\hline Average & 18.8 & 787.9 & 4805 & 3912.90 & 1075.36 & 15376.6 & 14119.27 & 224.18 & 982.45 & 758.36 & 207.45 & 1000 & 783.72 \\
\hline
\end{tabular}

The table 1 shows wholesale and retail price and marketing margin of inputs used in the production of fishery products during the period of 2004-2014. In this period of time marketing margin growth for warm water fish, cold-water fish, fishmeal and concentrate on average were 7.84, 7.03, 12.61 and 17.45 percent respectively. Comparison of this growth with moderate inflation rate shows that the increase in marketing margin of fisheries inputs has been less than inflation rate in this period.

Table 1. Fisheries input's price and marketing margin (Percent-Rials)

Resource: Iran Fisheries Organization, Statistics Center and Author's Calculation

\subsection{Statistics and Data Analysis}

\subsubsection{Results of Price Transmission and Marketing Margin}

The results of price transmission effect on marketing margin of the fisheries products show in table 2 . R2 statistics show that changes in the dependent variable (marketing margin for fisheries products), is explained by the explanatory variables of the model (rise and fall of the price variables of cool water fish and warm water fish 
(Larve and Fingerling), Fishmeal and Concentrate increase and decrease in marketing costs, the amount of fish and the time). The AIC and SBC statistics also suggest that interruption of any of the explanatory variables in the model have a significant impact on the market margins. In terms of marketing costs variables the results show that the increase in the cost of marketing indicator is positive which represents an increase of marketing expenses is directly related to marketing margin and reduction variable of marketing Costs expenses which is appeared with negative sign, Demonstrates that the decrease in marketing costs will decrease market margins and the differential of decrease in marketing costs is statistically significant. Also check the symmetry test of marketing costs transmission shows that Coefficients of reduction Variables in marketing costs was not statistically equal with marketing costs increase variables and it means that marketing costs are Asymmetric and Intermediaries are cause of increasing the market margins with asymmetric transfer of marketing costs to retail prices. Variable coefficients of increase and decrease of warm and cool water fish (Larve and Fingerling), Fishmeal and Concentrate (inputs) also state the asymmetry transmission between wholesale and retail prices, and this will lead to increased marketing margins. So that the increase in price of these inputs in wholesales leads to further increase in retail prices and reduction in the inputs prices in wholesale lead to a reduction in retail prices of these inputs. Therefore, although the impact of increase in inputs prices is lower that its reduction impact, However increase or decrease of input prices will lead to increase marketing margins. Hypothesis tests 3, 6 and 7 which are sufficient condition to detect the asymmetrical transmission of Marketing Cost and inputs prices are also rejected. Then mediators increase the market margins through the asymmetry transmission of Marketing Costs and inputs prices of retails. The positive coefficient of time process also shows that Marketing margins will increase over time. Total inputs variable which is also considered as an explanatory variable due to meet the in-scale constant return assumes in marketing margin, its effect on marketing margins was incremental and statistically significant.

Table 2 .

\begin{tabular}{lrr}
\hline \multicolumn{1}{c}{ Variables } & \multicolumn{2}{c}{ Coefficient } \\
\cline { 2 - 3 } & \multicolumn{1}{c}{ Cool water fish } & Warm water fish \\
\hline Intercept & $83.45^{*}(4.53)$ & $52.25^{*}(3.92)$ \\
Used input's value & $-0.00014^{*}(-4.05)$ & $-4.13 \mathrm{E}-06(-0.65)$ \\
Increase in wholesale prices of inputs & $-0.581^{*}(2.01)$ & $-0.431^{*}(11.15)$ \\
Decrease in wholesale prices of inputs & $-0.821^{*}(2.95)$ & $-0.452^{*}(11.25)$ \\
Increase in marketing costs & $0.0004^{*}(2.58)$ & $0.017^{*}(2.83)$ \\
Decrease in marketing costs & $-0.0008^{*}(2.35)$ & $-0.0008^{*}(6.30)$ \\
Time process & $0.15(0.31)$ & $0.49^{*}(5.99)$ \\
Insurance & $0.012(-0.81)$ & $0.0098^{*}(-5.90)$ \\
Complete transmission of the Concentrate price increase & rejected & rejected \\
Complete transmission of the Concentrate price decrease & rejected & accepted \\
Complete transmission of the fishmeal price increase & rejected & accepted \\
Complete transmission of the fishmeal price decrease & rejected & rejected \\
\hline Complete transmission of the cool water Fingerling price increase & rejected & -------- \\
Complete transmission of the cool water Fingerling price decrease & rejected & ------ \\
Complete transmission of the warm water Fingerling price increase & ------- & rejected \\
Complete transmission of the warm water Fingerling price decrease & ------ & rejected \\
Test prerequisite for symmetry transmission inputs prices & rejected & rejected \\
Test sufficiency for symmetry transmission inputs prices & rejected & rejected \\
Marketing costs transmission asymmetry test & rejected & rejected \\
Inputs Price transmission in short run is symmetric & rejected & rejected \\
Inputs Price transmission in long run is symmetric & rejected & rejected \\
\hline $\mathrm{R}^{2}$ & 0.99 & 0.99 \\
D.W & 1.51 & 2.03 \\
\hline
\end{tabular}

Note. The values in parentheses are the t-statistics. The * denotes statistical significant at the $5 \%$ level.

Resource: research finding.

\section{Discussion}

Our purpose of this paper was checking the Prices Transmission of Inputs and Marginal Costs on marketing 
margin of Fisheries Products (warm and cool fish). For this purpose, the data published by the website of Fisheries and Statistics Center of Iran, during the period 2004 to 2014 were used to extract the data needed for the price of hot and cold water fish prices (Larve and Fingerling), Fishmeal and Concentrate (inputs), Transportation and labor costs and the amount of required inputs. The results show that the Rising input price in the wholesale, input price reduction in the wholesale, the production and an increase in marketing costs variables Have a significant effect on the market margins of the fishery products So that the impact of all these variables on marketing margin of fishery products was were positive except marketing costs Reduction variable. The results also show that Transfer of rising and falling input prices from wholesale to retail As well as the increase and decrease of marketing costs were not conducted completely and Transfer of input prices in the short term and long term are asymmetric. In the other words the results show that the necessary and sufficient condition for asymmetric price transmission has rejected and mediators through to asymmetrical price transmission of inputs to retails increase marketing margins and thereby earn profit. The results of the Marketing margins assessment show that another way to increase marketing margins is Asymmetric transmission of marketing costs. Hence this failure of the fisheries marketing reduced the welfare of producers and consumers and increase marketing margins. To improve this situation it is suggested to establish the Notification institutions of market. These institutions can make the information on costs, prices and quantities of inputs and products in different regions of the country accessible. This will reduce the bargaining power of intermediaries, reduce price volatility and will prevent increase of market margins.

\section{References}

Aguiar, D. R. D., \& Santana, J. A. (2002). Asymmetry in farm to retail price transmission: evidence from Brazil. Agribusiness, 18(1), 37-48.

Bojnec, S. (2002). Price transmission and Marketing Margins in the Slovenian beef and pork Markets during Transition. Exploring Diversity in the European agri-Food System. Zaragoza (Spain): 362-370.

Brummer, B., Von Cramon Taubadel, S., \& Zorya, S. (2009). The Impact of Market and Policy Instability on price Transmission between Wheat and Flour in Ukraine. European Review of Agricultural Economics, 36(2), 203-230.

Buse, R. C., \& Brandow, G. E. (1960). The Relationship of Volume, Prices and Costs to Marketing Margins for farm foods. Agricultural and Applied Economics association, 42(2), 362-370.

Dawe, D., \& maltsoglou, I. (2014). Marketing Margins and the welfare of Food price Shocks. Journal of Food Policy, 46, 50-55.

Frigon, M., Doyon, M., \& Romail, R. (1999). Asymmetry in Farm-Retail price Transmission in the Northeastern Fluid Milk Market. Food Marketing Policy Center. Research Report.

Golitavana, M., Delavari, M., Sfandiari., A., \& Shakrzadeh, E. (2014). Vertical price Transmission in Cucumber Market of Iran. Indian Journal of Fundemental and applied Life Sciences, 4, 139-146.

Guillen, J., \& Franquesa, R. (2007). Analysis of the price transmission along the Spanish market chain for different seafood products. Retrieved from http://www.eafe-fish.eu

Heien, D. M. (1980). Markup Pricing in a Dynamic Model of the Food Industry. American Journal of Agricultural Economics, 62(1), 10-18.

Hosseini, S. S., Nikukar, A., \& Durandish, A. (2011). Analysis of Market structure and the effect of the price transmission on the marketing margin of the beef industry in Iran. Iranian Journal of Agricultural Economics and Development, 2(2-41), 157-147.

Kinnucan, H. W., \& Zhang, D. (2014). Notes on farm-retail price transmission and marketing margin behavior. Submitted journal of agricultural Economics.

Moghaddasi, R. (2009). Price Transmission in agricultural Market: An Iranian Experience. America-Eurasian Journal. Agric \& Environ, Sci., 6(1), 70-75.

Ojogho, O., Erhabor, P. O., Emokaro, C. O., \& Ahmadu, J. (2012). Marketing margin and price transmission analysis for beef in Benin Metropolis. International Journal of agricultural Economics \& rural development, 5(1), 63-73.

Pick, D. H., Karrenbrock, J., \& Carman, H. F. (1990). Price asymmetry and Marketing Margin Behavior: An Example for California-Arizona Citrus. Agribusiness, 6(1), 75-84.

Seif, Y., \& Mirzade Firoozabad, A. M. (2015). The impressionability of lamb marketing margin on asymmetric 
price transmission. Agriculture and Development, the twenty-second year, 88, 224-207.

Wohlgenant, M. K., \& Mullen, J. D. (1987). Modeling the Far-Retail Price Spread for beef. Western Journal of Agricultural Economics, 12(2), 119-125.

Wohlgenant, M. K. (2001). Marketing Margins: Empirical Analysis, Department of Agricultural and Resource Economics. North Carolina State University, Raleigh, NC. Chapter 16.

Zoltan, B., \& Lajos, F. I. (2000). Marketing Margins and Price Transmission on the Hungarian Beef Market. Institute of Economics, Hungarian Academy of sciences, 1-25.

\section{Copyrights}

Copyright for this article is retained by the author(s), with first publication rights granted to the journal.

This is an open-access article distributed under the terms and conditions of the Creative Commons Attribution license (http://creativecommons.org/licenses/by/3.0/). 